\title{
THE EFFECT OF EXPERIMENTAL VENOUS OBSTRUCTION ON SALT AND WATER DISTRIBUTION AND EXCRETION \\ IN MAN
}

\author{
By MARVIN F. LEVITT, ${ }^{1}$ LOUIS B. TURNER, ${ }^{2}$ AND AVRON Y. SWEET WITH THE \\ TECHNICAL ASSISTANCE OF CHARLOTTE SPANIER AND HERBERT HABER
}

(From the Departments of Medicine and Pediatrics, Mount Sinai Hospital, New York, N. Y.)

(Submitted for publication May 19, 1952; accepted August 1, 1952)

An acute increase in local venous pressure produces a pooling of blood in the congested area and an alteration of fluid exchange at the capillary wall (1). This pooling occurs quickly and when produced experimentally by tourniquets applied to three extremities, has been shown to trap a volume equivalent to about 15 to 20 per cent of the total circulating volume within 10 minutes $(2,3)$. Elevation of venous pressure, according to Starling's fundamental hypothesis, will, in addition, initiate a filtration of fluid out of the capillaries into the local tissues $(1,2)$. This peripheral loss of fluid produces a decreased plasma volume and a rise in plasma protein concentration and hematocrit. The diminution in effective blood volume results in decreased venous return, a decreased cardiac output, a fall in blood pressure and a compensatory reflex vasoconstriction $(4,5)$. The increased plasma protein concentration combined with the fall in blood pressure will evoke a diffusion of interstitial fluid into those areas of the capillary bed not exposed to increased pressures. The ultimate stabilization of blood pressure will depend upon the extent to which these mechanisms compensate, for the reduced circulating volume. The chain of events precipitated by the reduction in effective circulating volume is similar to that observed in dehydration and in hemorrhagic or traumatic shock (4-8).

The available evidence does not indicate whether or not, under the above circumstances, stores of electrolytes and water located outside of the fluid phase of the extracellular compartment contribute to the maintenance of plasma volume. Lands and Johnson suggested that hemorrhagic shock evoked a movement of intracellular water into the extracellular compartment (9). Stewart and Rourke

\footnotetext{
1 Sara Welt and Rosenstock Fellow in Medicine; Research Assistant in Medicine.

2 Dazian Fellow in Medicine; Research Assistant in Medicine.
}

concluded that blood loss was compensated, in part at least, by a movement of fluid from within the cells outward (10). In infants convalescing from dehydration due to diarrhea, a shift of water from the cells to the extracellular compartment has been noted (11). In conflict with these reports, Ashworth and Kregel found that cellular water increased at the expense of the extracellular volume after hemorrhage (12).

The use of recently described methods for measuring the distribution of water and electrolytes has suggested that significant stores of sodium and chloride are located outside of the fluid phase of the extracellular compartment (13-16). Such stores are labile and under appropriate stimuli may, in part, be transferred into this fluid phase (1721). Using these techniques, an attempt has been made here to determine whether the systemic effects produced by local interference with venous flow include such an endogenous shift of electrolytes and water.

\section{METHODS}

The volume of the fluid phase of the extracellular compartment before and after the application of tourniquets was measured as the volume of distribution of inulin. Because the post-infusion method (13-16) for determining the inulin space permits only a single measurement in any 24-hour period, we have employed the difference method $(20,22,23)$. The amount of inulin retained at any one instant is calculated as the difference between the total infused and the cumulative excretion. The latter technique permits serial space measurements over relatively brief periods of time so that acute changes may be detected. Both the post-infusion and difference methods afford identical volumes of distribution when urinary recovery of inulin is complete $(20,22-24)$.

Ten fasting adults were used in this study. Urine and plasma were collected for proper control determinations. An intravenous infusion containing 3.6 grams per cent of inulin and $100 \mathrm{mEq}$. per liter of sodium chloride was then administered from a calibrated burette accurate to $0.5 \mathrm{cc}$. In lieu of a priming injection, the infusion was started at 
a rate of 8 to $10 \mathrm{cc}$. per minute and then during the first 15 minutes gradually reduced stepwise to $0.8 \mathrm{cc}$. per minute. This rate, maintained constant to within \pm 1 per cent with a Bowman infusion pump, provided plasma levels of inulin between 30 and $50 \mathrm{mg}$. per cent. After four to four and a half hours of infusion, a period of time adequate to provide equilibrium distribution $(13,15,16$, $20)$, the bladder was catheterized and rinsed with distilled water and air. Directly before emptying the bladder, plasma was drawn for inulin and electrolyte analyses, and the volume of solution infused was read from the burette. A second control space was similarly measured five and a half to six hours after the start of the infusion.

After two control determinations of extracellular space were obtained, blood pressure cuffs were applied to both upper thighs in eight of 10 patients and inflated to pressures $5-10 \mathrm{~mm}$. $\mathrm{Hg}$ below diastolic pressure so that venous flow was markedly obstructed. Systemic blood pressure was followed at frequent intervals and the pressure in the obstructing cuffs constantly adjusted to subdiastolic levels. The cuffs were kept in place for about three hours throughout which time no change was made in the rate of the inulin infusion. During this period additional measurements of extracellular space were made one to two hours and two to three hours after application of the tourniquets. The fluid level in the burette was read frequently to determine the constancy of the infusion rate. Plasma for inulin and electrolyte analyses was drawn from the non-involved arm before each bladder washout and at intervals of $\mathbf{3 0}$ minutes. In three patients several blood samples were drawn from the congested veins below the tourniquets simultaneously with the blood from the arm vein. After the final bladder washout the infusion was discontinued, the tourniquets removed and urine was collected for 18 to 24 hours to determine the completeness of recovery of the administered inulin. In two control patients serial space measurements were made at identical intervals without the application of tourniquets.

Each infusion and plasma and urine sample was analyzed for inulin four to 10 times by the resorcinol method of Schreiner (25). Spaces were calculated as the amount of inulin retained divided by the simultaneous plasma concentration in the non-congested upper extremity. Inulin clearances (GFR) were determined by the usual method (26), but the long intervals between bladder emptying provided only three to four periods (each of one to one and a half hours) in each patient.

Sodium and potassium concentrations were measured in an internally compensated Perkin-Elmer flame photometer. Chloride concentrations were determined by the Van Slyke and Hiller modification of the Sendroy method (27), plasma protein concentrations by the biuret technique (28), and venous hematocrit with the standard Wintrobe tube.

The electrolyte contained in the fluid phase of the extracellular compartment was calculated as the product of the inulin space and the plasma electrolyte concen-

8 Technique, for attaining equilibrium distribution of inulin more quickly, suggested by Dr. Domingo Gomez. tration without corrections for Donnan's equilibrium. Throughout the experimental period, which lasted eight hours, each patient ingested two glasses of water, one during the control period and one about an hour after the application of tourniquets. During the tourniquet period a total of 12 to $14 \mathrm{mEq}$. of sodium chloride was infused, a variable proportion of which was retained.

\section{RESULTS}

Within minutes after the inflation of the tourniquets, marked rubor and congestion of the legs developed and persisted throughout the tourniquetperiod. In three of the patients slight but definite pitting edema became apparent after one to two hours. Where pitting edema was not elicited, a thickening and induration of the subcutaneous tissue appeared. All subjects noted a sense of constriction and numbness but none complained of pain.

Of the eight patients so studied, three manifested moderate to marked reductions in blood pressure (Table I). Maximum falls in blood pressure occurred 60 to 90 minutes after inflation of the tourniquets and were accompanied by other signs of shock (salivation, nausea, vomiting in one patient, diaphoresis, pallor). In these patients the cuffs were temporarily partially deflated in order to maintain subdiastolic pressures. The shock-like reaction persisted for only three to 10 minutes despite the continued application of the tourniquets. During the last one and a half hours of the tourniquet period, the blood pressures gradually reverted toward control values. These three patients were the only subjects in the series whose control diastolic pressure exceeded $90 \mathrm{~mm}$. of mercury. In five subjects little or no reduction of blood pressure occurred and no other untoward effects were noted.

The two control pre-tourniquet inulin spaces differed by less than 3 per cent. The control space listed in Table $I$ is the second of these two pretourniquet determinations." Following inflation of the tourniquets, each of the eight patients showed an increase in the volume of distribution of inulin. The increases recorded in Table $I$ and Figure 1 averaged 16 per cent $(1,400 \mathrm{cc}$.) with a range

In one patient (Pan) only a single control space was measured after 4 hours of inulin infusion, but a similar control study performed subsequently demonstrated that equilibrium had been attained within 4 hours. 
TABLE I

The effect of experimental venous obstruction on blood pressure, plasma protein concentration, inulin space, plasma electrolyte concentration, glomerular filtration rate and electrolyte excretion

\begin{tabular}{|c|c|c|c|c|c|c|c|c|c|c|c|c|c|c|c|}
\hline \multirow[b]{2}{*}{ Sub- } & \multirow[b]{2}{*}{$\underset{(\min .)}{\text { Time* }}$} & \multirow[b]{2}{*}{$\underset{\substack{\text { Blood } \\
\text { pressure } \\
\underset{\boldsymbol{H} \boldsymbol{m})}{(\mathbf{m})}}}{ }$} & \multirow[b]{2}{*}{$\begin{array}{l}\text { Total } \\
\text { protein } \\
\text { (gm. } \\
\text { per cent) }\end{array}$} & \multirow[b]{2}{*}{$\begin{array}{c}\text { Inulin } \\
\text { space } \\
(c c .)\end{array}$} & \multicolumn{3}{|c|}{$\begin{array}{l}\text { Serum electrolyte } \\
\text { concentrations }\end{array}$} & \multicolumn{2}{|c|}{$\begin{array}{l}\text { Total electro- } \\
\text { lyte in ECF }\end{array}$} & \multirow{2}{*}{$\begin{array}{l}\text { Inulin } \\
\text { clear- } \\
\text { ance } \\
(c c . \mid \\
\text { min.) }\end{array}$} & \multirow[b]{2}{*}{$\begin{array}{c}\text { Urine } \\
\text { flow } \\
\text { (cc.l } \\
\text { min.) }\end{array}$} & \multicolumn{3}{|c|}{$\begin{array}{l}\text { Electrolyte } \\
\text { excretion }\end{array}$} & \multirow[b]{2}{*}{ Comment } \\
\hline & & & & & $\overbrace{\substack{\mathrm{Na} \\
l .}}$ & 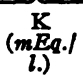 & $\underset{(m E q . l}{C l}$ & $\overbrace{\left(m E_{q .}\right)}^{\text {Iyce in }}$ & $\frac{\mathrm{Cl}}{(m E q)}$ & & & 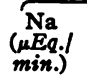 & $\underset{\text { mix. })}{\left(\mu \dot{E}_{q . /}\right.}$ & 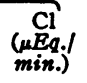 & \\
\hline \multirow[t]{2}{*}{$\overline{\text { Wee }}$} & $\begin{array}{c}\text { Control } \\
22 \\
82 \\
119 \\
188\end{array}$ & $\begin{array}{l}165 / 95 \\
148 / 96 \\
115 / 70 \\
125 / 80 \\
144 / 90\end{array}$ & $\begin{array}{l}7.8 \\
7.5 \\
8.3 \\
7.8 \\
7.5\end{array}$ & $\begin{array}{r}8,570 \\
9,320 \\
10,200\end{array}$ & $\begin{array}{l}143 \\
140 \\
148 \\
146 \\
137\end{array}$ & $\begin{array}{l}4.7 \\
4.5 \\
4.7 \\
4.9 \\
4.8\end{array}$ & $\begin{array}{l}109 \\
107 \\
111 \\
112 \\
106\end{array}$ & $\begin{array}{l}1,220 \\
1.360 \\
1,400\end{array}$ & $\begin{array}{r}934 \\
1,040 \\
1,080\end{array}$ & $\begin{array}{l}64 \\
43 \\
58\end{array}$ & $\begin{array}{l}.48 \\
.38\end{array}$ & $\begin{array}{r}11 \\
4 \\
2\end{array}$ & $\begin{array}{l}24 \\
27 \\
20\end{array}$ & $\begin{array}{r}19 \\
9 \\
10\end{array}$ & $\begin{array}{l}\text { Transient shock } \\
\text { at 60-65 min. }\end{array}$ \\
\hline & \multicolumn{2}{|c|}{ Total increase } & & 1,630 & & & & 180 & 144 & & & & & & \\
\hline \multirow[t]{2}{*}{ Par } & $\begin{array}{c}\text { Control } \\
60 \\
115 \\
147\end{array}$ & $\begin{array}{l}110 / 70 \\
106 / 70 \\
110 / 80\end{array}$ & $\begin{array}{l}6.9 \\
7.5 \\
8.0 \\
7.4\end{array}$ & $\begin{array}{l}7,500 \\
8,400\end{array}$ & \multirow[t]{2}{*}{$\begin{array}{l}136 \\
133 \\
132 \\
136\end{array}$} & \multirow[t]{2}{*}{$\begin{array}{l}4.3 \\
4.4 \\
4.2 \\
4.3\end{array}$} & \multirow[t]{2}{*}{$\begin{array}{l}112 \\
112 \\
108 \\
109\end{array}$} & $\begin{array}{l}1,020 \\
1,140\end{array}$ & $\begin{array}{l}840 \\
916\end{array}$ & $\begin{array}{l}61 \\
59\end{array}$ & $\begin{array}{l}.49 \\
.52\end{array}$ & $\begin{array}{l}361 \\
445\end{array}$ & $\begin{array}{l}650 \\
420\end{array}$ & $\begin{array}{l}517 \\
525\end{array}$ & $\begin{array}{l}\text { No untoward } \\
\text { effects }\end{array}$ \\
\hline & \multicolumn{2}{|c|}{ Total increase } & & 900 & & & & 120 & 76 & & & & & & \\
\hline \multirow[t]{2}{*}{ Col } & $\begin{array}{c}\text { Control } \\
62 \\
123\end{array}$ & $\begin{array}{l}110 / 80 \\
110 / 84 \\
104 / 76\end{array}$ & $\begin{array}{l}6.7 \\
7.3 \\
7.4\end{array}$ & $\begin{array}{l}7,420 \\
7,740 \\
8,700\end{array}$ & $\begin{array}{l}132 \\
135 \\
139\end{array}$ & $\begin{array}{l}4.4 \\
4.3 \\
4.5\end{array}$ & $\begin{array}{l}113 \\
111 \\
110\end{array}$ & $\begin{array}{r}980 \\
1,040 \\
1,210\end{array}$ & $\begin{array}{l}839 \\
859 \\
957\end{array}$ & $\begin{array}{l}85 \\
65 \\
50\end{array}$ & $\begin{array}{r}2.78 \\
.76 \\
1.27\end{array}$ & $\begin{array}{r}321 \\
124 \\
36\end{array}$ & $\begin{array}{l}42 \\
18 \\
16\end{array}$ & $\begin{array}{r}361 \\
140 \\
51\end{array}$ & $\begin{array}{l}\text { No untoward } \\
\text { effects }\end{array}$ \\
\hline & \multicolumn{2}{|c|}{ Total increase } & & 1,280 & & & & 230 & 118 & & & & & & \\
\hline \multirow[t]{2}{*}{ Bro } & $\begin{array}{c}\text { Control } \\
20 \\
60 \\
96 \\
110 \\
134\end{array}$ & $\begin{array}{c}190 / 110 \\
190 / 130 \\
164 / 126 \\
60 / 45 \\
100 / 80 \\
116 / 80\end{array}$ & $\begin{array}{l}7.3 \\
7.5 \\
7.5 \\
7.1\end{array}$ & 9,210 & $\begin{array}{l}146 \\
145 \\
142 \\
147\end{array}$ & $\begin{array}{l}\mathbf{3 . 4} \\
\mathbf{3 . 3} \\
\mathbf{3 . 8} \\
\mathbf{3 . 3}\end{array}$ & $\begin{array}{l}109 \\
106 \\
108 \\
108\end{array}$ & 1,570 & 1,000 & 49 & 2.3 & 366 & 17 & 232 & \multirow[t]{2}{*}{$\begin{array}{l}\text { Transient shock } \\
\text { at } 90-95 \mathrm{~min} \text {. }\end{array}$} \\
\hline & \multicolumn{2}{|c|}{ Total increase } & & 1,490 & & & & 220 & 160 & & & & & & \\
\hline \multirow[t]{2}{*}{ Pan } & $\begin{array}{c}\text { Control } \\
64 \\
127 \\
189\end{array}$ & $100 / 60$ & $\begin{array}{l}6.8 \\
8.3 \\
8.0\end{array}$ & $\begin{array}{l}6,600 \\
8,030\end{array}$ & $\begin{array}{l}137 \\
149 \\
147 \\
143\end{array}$ & $\begin{array}{l}4.4 \\
4.4 \\
4.4 \\
4.3\end{array}$ & $\begin{array}{l}114 \\
122 \\
113 \\
113\end{array}$ & $\begin{array}{r}904 \\
1,150\end{array}$ & $\begin{array}{l}753 \\
907\end{array}$ & $\begin{array}{l}75 \\
65\end{array}$ & $\begin{array}{r}.96 \\
1.28\end{array}$ & $\begin{array}{l}117 \\
113\end{array}$ & $\begin{array}{l}32 \\
22\end{array}$ & $\begin{array}{l}82 \\
88\end{array}$ & $\begin{array}{l}\text { No untoward } \\
\text { effects }\end{array}$ \\
\hline & Total i & increase & & 1,430 & & & & 246 & 154 & & & & & & \\
\hline Os8 & $\begin{array}{c}\text { Control } \\
45 \\
65 \\
85 \\
105 \\
120 \\
141 \\
+ \text { Tolal }\end{array}$ & $\begin{array}{r}140 / 90 \\
138 / 80 \\
110 / 78 \\
88 / 68 \\
110 / 74 \\
130 / 80 \\
150 / 90 \\
\text { increase }\end{array}$ & $\begin{array}{l}6.8 \\
7.5 \\
7.2 \\
7.5 \\
7.5\end{array}$ & $\begin{array}{r}9,470 \\
10,300\end{array}$ & $\begin{array}{l}135 \\
138 \\
151 \\
140 \\
133\end{array}$ & 5.0 & $\begin{array}{l}105 \\
104 \\
104 \\
107 \\
104\end{array}$ & $\begin{array}{r}1,320 \\
40\end{array}$ & $\begin{array}{r}994 \\
1,070\end{array}$ & $\begin{array}{l}85 \\
60\end{array}$ & $\begin{array}{r}1.01 \\
.67\end{array}$ & $\begin{array}{l}216 \\
120\end{array}$ & $\begin{array}{l}66 \\
58\end{array}$ & $\begin{array}{l}264 \\
160\end{array}$ & $\begin{array}{l}\text { Transient shock } \\
\text { at } 85-90 \text { min. } \\
\text { Copious vomit- } \\
\text { ing at } 105-150 \\
\text { min. }\end{array}$ \\
\hline Ban & $\begin{array}{c}\text { Control } \\
56 \\
118 \\
156\end{array}$ & $\begin{array}{l}130 / 76 \\
122 / 70 \\
114 / 76 \\
116 / 76\end{array}$ & $\begin{array}{l}7.4 \\
7.1 \\
7.0 \\
7.2\end{array}$ & $\begin{array}{l}12,200 \\
14,800\end{array}$ & $\begin{array}{l}140 \\
138 \\
138 \\
142\end{array}$ & $\begin{array}{l}4.1 \\
3.6 \\
3.4 \\
3.7\end{array}$ & $\begin{array}{l}107 \\
110 \\
111 \\
108\end{array}$ & $\begin{array}{l}1,710 \\
2,100\end{array}$ & $\begin{array}{l}1,310 \\
1,600\end{array}$ & $\begin{array}{l}83 \\
82\end{array}$ & $\begin{array}{l}.91 \\
.47\end{array}$ & & & & $\begin{array}{l}\text { No untoward } \\
\text { effects }\end{array}$ \\
\hline & Total i & increase & & 2,600 & & & & 390 & 290 & & & & & & \\
\hline Ben & $\begin{array}{c}\text { Control } \\
44 \\
81 \\
119 \\
153\end{array}$ & $\begin{array}{l}110 / 76 \\
106 / 70 \\
100 / 78 \\
110 / 80 \\
110 / 80\end{array}$ & $\begin{array}{l}\mathbf{8 . 6} \\
\mathbf{8 . 1} \\
\mathbf{8 . 6} \\
\mathbf{8 . 4} \\
\mathbf{8 . 3}\end{array}$ & $\begin{array}{l}12,000 \\
12,800 \\
13,100\end{array}$ & $\begin{array}{l}136 \\
135 \\
132 \\
130 \\
133\end{array}$ & $\begin{array}{l}3.0 \\
3.1 \\
2.9 \\
2.9 \\
2.8\end{array}$ & $\begin{array}{l}105 \\
105 \\
106 \\
104 \\
103\end{array}$ & $\begin{array}{l}1,630 \\
1,690 \\
1,740\end{array}$ & $\begin{array}{l}1,260 \\
1,360 \\
1,350\end{array}$ & $\begin{array}{l}106 \\
101 \\
111\end{array}$ & $\begin{array}{l}.56 \\
.51 \\
.36\end{array}$ & $\begin{array}{l}33 \\
48 \\
11\end{array}$ & $\begin{array}{l}.2 \\
1.7 \\
4.8\end{array}$ & $\begin{array}{l}28 \\
39 \\
21\end{array}$ & $\begin{array}{l}\text { No untoward } \\
\text { effects }\end{array}$ \\
\hline & Total i & increase & & 1,100 & & & & 110 & 90 & & & & & & \\
\hline & & & & & & ontrol p & patients- & -no tour & niquets & plied & & & & & \\
\hline Hall & $\begin{array}{c}\text { Control } \\
63 \\
115\end{array}$ & $\begin{array}{c}95 / 60 \\
\text { unchanged }\end{array}$ & $\begin{array}{l}6.7 \\
6.3 \\
6.3\end{array}$ & $\begin{array}{l}8,850 \\
8,640 \\
8,750\end{array}$ & $\begin{array}{l}144 \\
143 \\
144\end{array}$ & $\begin{array}{l}4.3 \\
4.1 \\
4.3\end{array}$ & $\begin{array}{l}113 \\
110 \\
111\end{array}$ & $\begin{array}{l}1,270 \\
1,240 \\
1,260\end{array}$ & $\begin{array}{l}995 \\
950 \\
972\end{array}$ & $\begin{array}{l}103 \\
100 \\
101\end{array}$ & $\begin{array}{l}1.3 \\
3.0 \\
3.2\end{array}$ & $\begin{array}{l}277 \\
233 \\
224\end{array}$ & $\begin{array}{l}54 \\
81 \\
66\end{array}$ & $\begin{array}{l}292 \\
272 \\
241\end{array}$ & \\
\hline & Tolal & change & & -50 & & & & -10 & -23 & & & & & & \\
\hline Bro & $\begin{array}{c}\text { Control } \\
62 \\
131\end{array}$ & $\begin{array}{c}190 / 110 \\
\text { unchanged }\end{array}$ & $\begin{array}{l}6.7 \\
6.7 \\
7.3\end{array}$ & $\begin{array}{l}11,300 \\
11,300 \\
11,200\end{array}$ & $\begin{array}{l}138 \\
138 \\
136\end{array}$ & $\begin{array}{l}3.7 \\
3.8 \\
3.9\end{array}$ & $\begin{array}{l}108 \\
109 \\
109\end{array}$ & $\begin{array}{l}1,560 \\
1,560 \\
1,520\end{array}$ & $\begin{array}{l}1,220 \\
1,230 \\
1,220\end{array}$ & $\begin{array}{l}56 \\
56 \\
51\end{array}$ & $\begin{array}{l}2.1 \\
1.8 \\
1.5\end{array}$ & $\begin{array}{l}248 \\
249 \\
222\end{array}$ & $\begin{array}{l}25 \\
16 \\
15\end{array}$ & $\begin{array}{l}250 \\
278 \\
238\end{array}$ & \\
\hline & Total & change & & -100 & & & & -40 & 0 & & & & & & \\
\hline
\end{tabular}

* Time represents that number of minutes after the application of tourniquets.

† In this patient 65 minutes of venous congestion induced an expansion of the inulin space of $830 \mathrm{cc}$. and an increment of total extracellular sodium and chloride of $280 \mathrm{mEq}$. and $76 \mathrm{mEq}$., respectively. The subsequent fall accompanied a period of repeated and copious vomiting. 

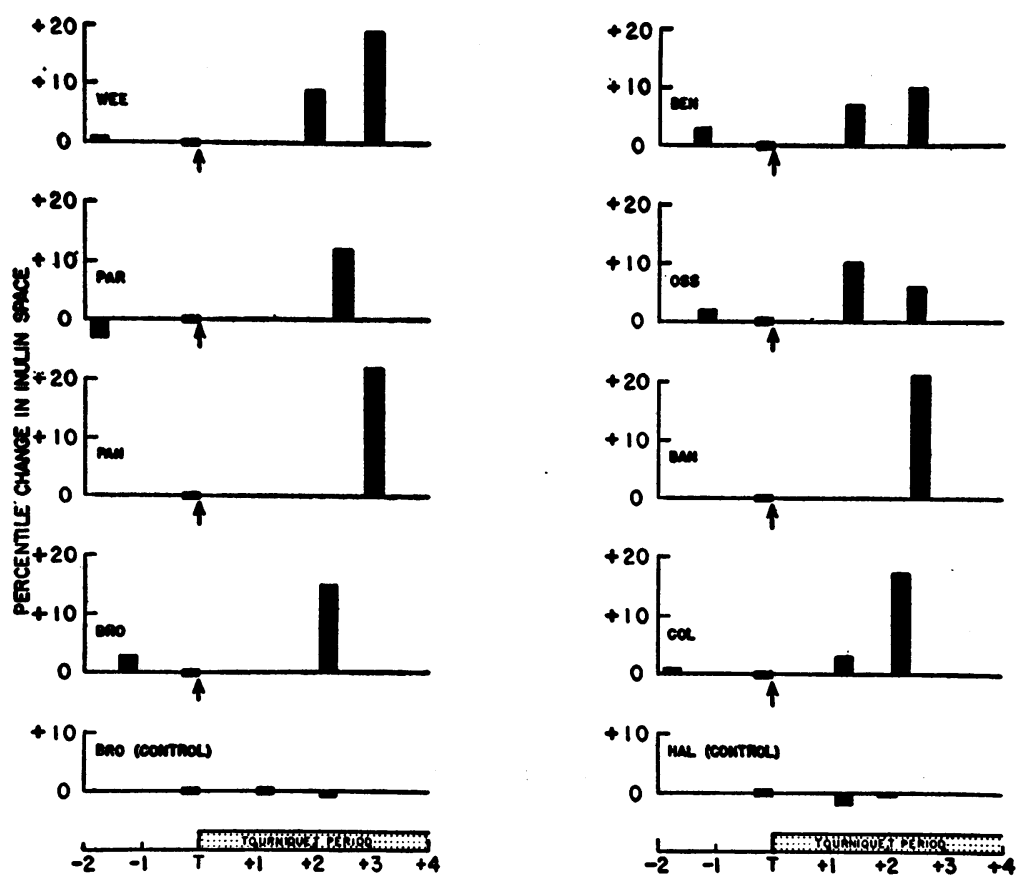

TIME (HOURS)

Fig. 1. Changes in Inulin Space Before and After Application of Tourniguets in Eight Experimental Subjects and During Comparable Time Intervals in Two Control Subjects

Arrows represent time of tourniquet application.

from 9 to 21 per cent. The maximum increase in the inulin space occurred two to three hours after tourniquet application. In one patient (Oss) the maximum increase occurred after one hour of venous obstruction; this patient, however, vomited profusely during the latter part of the tourniquet period.

Between 30 and 60 minutes after inflation of the tourniquets, the plasma inulin concentration in- creased in five of the eight patients to levels of 5 to $15 \mathrm{mg}$. per cent above control values. Thereafter the inulin concentration remained fairly constant or decreased slightly. Three patients showed no significant change in the plasma inulin concentration. In the three subjects in whom simultaneous plasma inulin concentrations were measured above and below the tourniquets, the latter concentration rose more slowly but finally approached

TABLE II

Detailed data including the plasma inulin concentrations, the quantity of inulin infused, excreted and retained, and the calculated inulin spaces from two typical experiments

\begin{tabular}{|c|c|c|c|c|c|c|c|}
\hline Subject & $\begin{array}{c}\text { Time from onset } \\
\text { of infusion } \\
\text { (hr.-min.) }\end{array}$ & $\begin{array}{c}\text { Inulin plasma } \\
\text { concentration } \\
\text { (mg. per cent) } \\
\text { a }\end{array}$ & $\begin{array}{c}\text { Inulin infused } \\
\text { during period } \\
\underset{(\mathrm{gm} .)}{\mathrm{b}}\end{array}$ & $\begin{array}{c}\text { Inulin excreted } \\
\text { during period } \\
\underset{(\mathrm{gm} .)}{\mathrm{c}}\end{array}$ & $\begin{array}{c}\text { Inulin retained } \\
\text { during period } \\
(\mathrm{gm} .) \\
\mathrm{b}-\mathrm{c}\end{array}$ & $\begin{array}{c}\begin{array}{c}\text { Inulin retained - } \\
\text { cumulative } \\
(\mathbf{g m} .) \\
\Sigma(\mathbf{b}-\mathrm{c})\end{array}\end{array}$ & $\begin{array}{c}\text { Inulin space } \\
(c c .) \\
\Sigma(b-c) / a\end{array}$ \\
\hline Col & $\begin{array}{l}4-6 \\
5-6 \\
5-17 \\
6-19 \\
7-20\end{array}$ & $\begin{array}{l}38.1 \\
38.7 \\
44.0 \\
45.6\end{array}$ & $\begin{array}{r}10.23 \\
2.05 \\
2.53 \\
1.93\end{array}$ & $\begin{array}{l}7.37 \\
2.04 \\
\text { Blood } \\
1.99 \\
1.37\end{array}$ & $\begin{array}{c}2.86 \\
.01 \\
\text { pressure cuffs } \\
.54 \\
.56\end{array}$ & $\begin{array}{r}2.86 \\
2.87 \\
\text { ipplied } \\
3.41 \\
3.97\end{array}$ & $\begin{array}{l}7,510 \\
7,420 \\
7,740 \\
8,700\end{array}$ \\
\hline $\mathrm{Hal}$ & $\begin{array}{c}\text { ntrol subject- } \\
5-21 \\
6-34 \\
7-26\end{array}$ & $\begin{array}{l}\text { uffs not appl } \\
32.0 \\
33.8 \\
33.8\end{array}$ & $\begin{array}{r}13.55 \\
2.15 \\
1.79\end{array}$ & $\begin{array}{r}10.73 \\
2.05 \\
1.75\end{array}$ & $\begin{array}{r}2.82 \\
.10 \\
.04\end{array}$ & $\begin{array}{l}2.82 \\
2.92 \\
2.96\end{array}$ & $\begin{array}{l}8,800 \\
8,640 \\
8,750\end{array}$ \\
\hline
\end{tabular}


within 1 to $5 \mathrm{mg}$. per cent of the systemic plasma concentrations. The amount of inulin retained during the tourniquet period was proportionately greater than the coincident increase in systemic plasma concentration and, therefore, each patient evinced an expansion of the inulin space (Table I). In two patients in whom tourniquets were not applied no change in inulin space was detected during comparable time periods (Figure 1 and Table I-control patients). Table II records the detailed inulin data from two typical experiments.

Post-infusion urinary collections were complete in eight of the 10 patients studied. The inulin re- coveries in these eight cases averaged 99.6 per cent with a range from 96.8 to 104 per cent.

Serial measurements of plasma protein concentration during the tourniquet period revealed increases in six of the eight patients (Table I). These changes were maximal after one to two hours of reduced venous flow and thereafter in four of these six subjects the protein concentration tended to return toward normal (Table I, Figure 2).

In five of the eight patients, no significant changes in plasma sodium or chloride concentrations were evident during the tourniquet period.

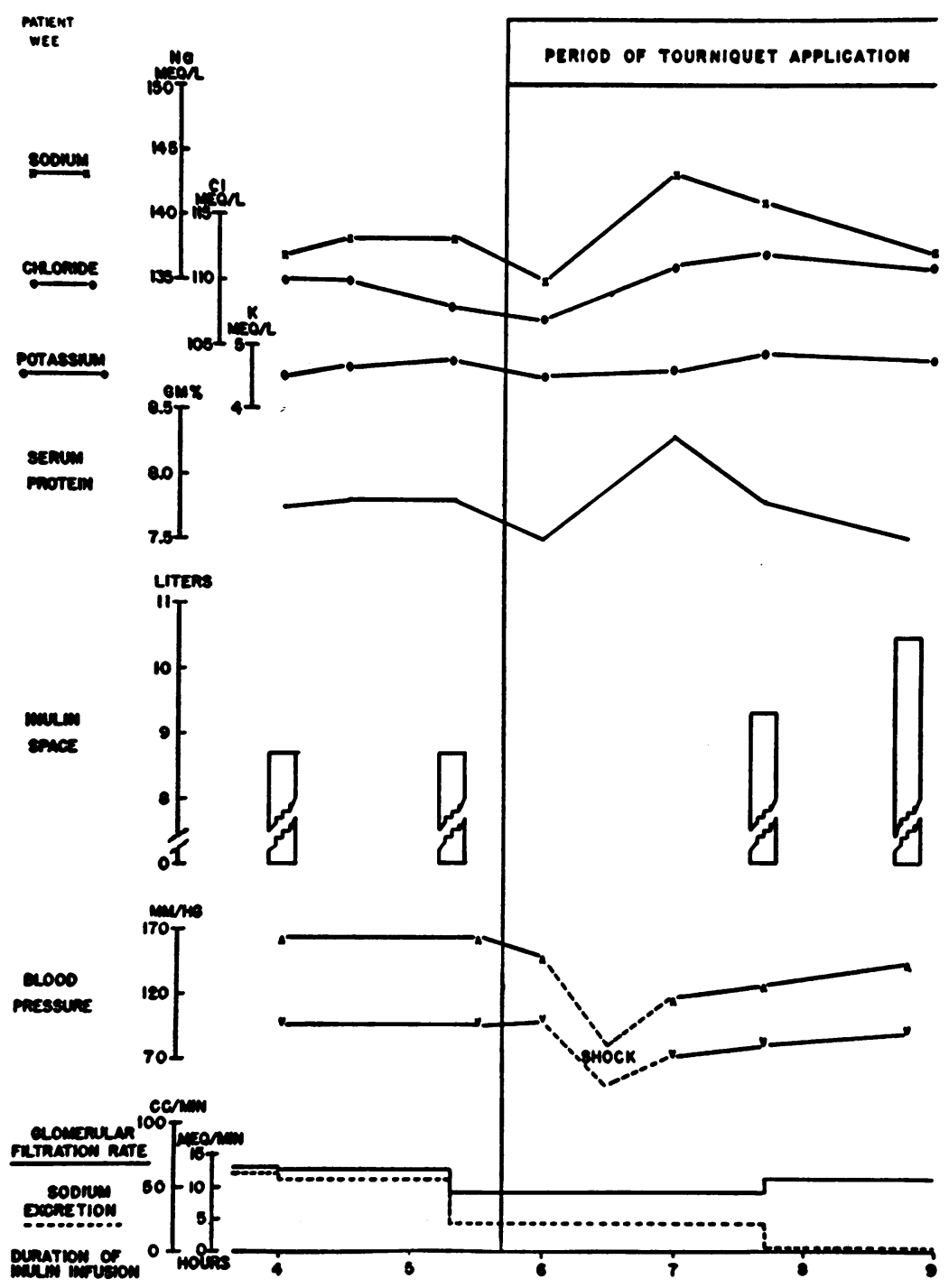

Fig. 2. Simultaneous Changes in Plasma Electrolyte Concentrations, Plasma Protein, Inulin Space, Blood Pressure, GFr and Salt Excretion in one Typical Experimental Subject 
In three patients (Wee, Pan, Oss), however, the plasma sodium concentrations increased one hour after the application of the tourniquets and then gradually returned to control or subcontrol levels (Table I, Figure 2). Similar, but smaller changes in chloride concentrations were noted in two of these patients. The increase in sodium and chloride contained in the inulin space averaged 190 and $140 \mathrm{mEq}$., respectively (Table I, Figure 3 ).

A decrease in glomerular filtration rate (GFR), of more than 15 per cent, was noted during the tourniquet period in five of the eight patients (Table I). This decrement was most marked in the first hour of venous obstruction and was associated with a reduction in blood pressure in three patients. In two of these five subjects the GFR approached control values during the latter phase of the tourniquet period.

Five of seven patients evinced a marked decrease in sodium excretion following the application of tourniquets (Table I). Generally, this reduction was associated with a simultaneous decrease in GFR. However, in three patients in whom the filtration rate remained unchanged or

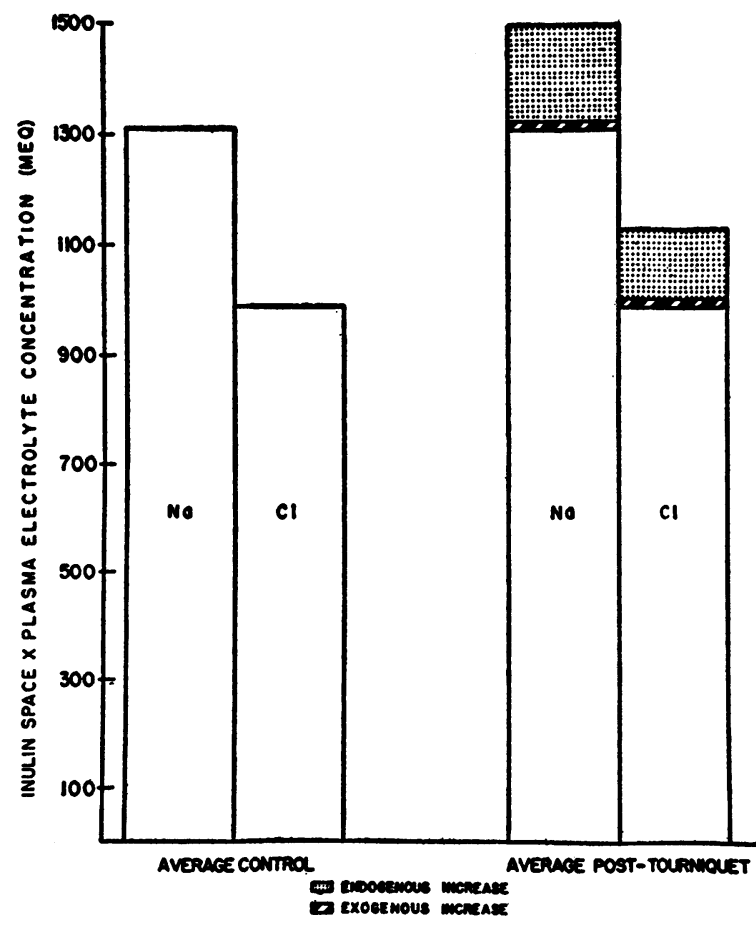

Fig. 3. Average Increase in Electrolyte Contained in the Inulin Space after Two to Three Hours of Reduced Venous Flow increased during the latter phase of the tourniquet period, the rate of sodium excretion continued to decrease (Table I, Figure 2). The changes in chloride excretion were generally similar to those noted in sodium excretion. No consistent alterations were detected in the rate of potassium excretion. The rate of urine flow remained essentially unchanged in four subjects (Wee, Par, Pan, Ben), fell transiently in one ( $\mathrm{Col})$, and showed a sustained fall in three (Bro, Oss, Ban) (Table I).

\section{DISCUSSION}

In evaluating the inulin space expansions noted during the tourniquet period, four possible sources of methodological error must be considered: 1) a failure to attain the maximum volume of distribution of inulin (equilibrium distribution) prior to the application of the tourniquets ; 2) errors in the analyses of the urine, plasma or infusion samples; 3 ) an increase in renal dead space during venous congestion ; 4) a state of disequilibrium produced by the experimental conditions and characterized by a concentration of inulin in the interstitial fluid higher than that of plasma.

Figure 1 and the examples shown in Table II reveal that the maximum volume of distribution of inulin was achieved after four to four and a half hours of infusion. Two control space determinations before the application of tourniquets and three consecutive space measurements in the control patients in whom venous flow was not obstructed agreed within 3 per cent. These findings indicate that uniform distribution had been achieved before the inflation of the tourniquets.

The multiple analyses of the urine, plasma and infusion provided a mean concentration with a standard deviation of \pm 2 per cent. In the first prolonged equilibrating period in which large amounts of inulin were infused and excreted, a 2 per cent error in both quantities may produce a significant error in the calculated control space. Since subsequent changes in space depend upon the amount of inulin retained during the specific period in question, the absolute change in the inulin space will not be significantly influenced by any error in the calculated volume of the control space. In the interval periods about $2 \mathrm{gm}$. of inulin were infused and excreted; 2 per cent errors in determining these quantities could produce a maximal 
expansion of about $200 \mathrm{cc}$. To account for the average expansion of $1,400 \mathrm{cc}$., an error of 20 to 25 per cent in overestimating the amount infused or in underestimating the amount excreted in any specific post-tourniquet period would be required. Such consistent discrepancies hardly appear plausible.

In the three subjects in whom venous congestion induced a sustained fall in urine flow, it is conceivable that a significant increase in the amount of inulin contained within the renal dead space occurred, thereby artificially augmenting the calculated space. However, two control studies have revealed that comparable falls in urine flow induced by pitressin may artificially expand the inulin space by only 100 to $300 \mathrm{cc}$. The dead space error may, therefore, account for only a small fraction of the space increase in these three subjects.

In the five subjects who showed a fall in glomerular filtration rate, increases in plasma inulin concentration occurred about 30 to 60 minutes after inflation of the tourniquets. That this rise in plasma concentration was not immediately distributed throughout the inulin space is suggested by the slower rise in inulin concentration in the venous blood drawn from the congested extremities. This discrepancy between the plasma concentration in the non-congested and congested areas probably resulted from the fact that considerable quantities of plasma ultrafiltrate were accumulated in the congested legs before the rise in inulin concentration occurred. However, since all space calculations were based on the higher plasma concentration in the non-congested area, any delay in the even distribution of this increment in concentration could only obscure an expansion in the inulin space. The stabilization of the inulin concentration during the last one and a half hours of the tourniquet-period in these five subjects and the absence of any significant change in inulin concentration in three subjects suggests that virtual equilibrium distribution was again achieved before the final space measurements.

The conceivable sources of error do not explain the consistent expansion in the volume of distribution of inulin after two to three hours of venous congestion in the lower extremities. That this increase was not a result of inulin metabolism is confirmed by the completeness of urinary recovery.

The arguments which imply that the volume of distribution of inulin affords a reliable estimate of the extracellular fluid volume have been previously presented $(13-16,20,22,23,29)$. The concept of a homogeneous, entirely fluid, extracellular compartment with precise, sharply defined boundaries undoubtedly represents an oversimplification. It has been contended that certain extracellular areas are rendered inaccessible to the inulin molecule by a difference in the architecture of the underlying medium $(30,31)$. Relatively solid phases as contained in bone and connective tissue (tendon) are probably not included in such space measurements (32). The recent demonstration of the identity of the volume of distribution of inulin with that of sucrose (23), mannitol (33), ferrocyanide (22), and radiosulfate (34) suggests, however, that a finite and measurable fluid phase of the extracellular compartment probably exists. It is in this sense-that of a fluid phase in rapid exchange with the plasma and with the chemical composition of an ultrafiltrate of plasma (13) that the terms extracellular fluid and interstitial fluid are used in this paper.

During the two to three hour period of reduced venous return, the total amount of salt administered in the inulin infusion equaled 12 to $14 \mathrm{mEq}$. Although the majority of these patients showed a reduction in salt excretion and thereby retained much of this amount, the positive exogenous balance can account for at most 5 to 10 per cent of the total increase in electrolyte contained in the inulin space. Accordingly, averages of about 180 $\mathrm{mEq}$. of sodium, $130 \mathrm{mEq}$. of chloride and 1,300 cc. of water appear to have been transferred into the fluid phase of the extracellular compartment from endogenous sources during this period (Figure 3). The precise source of this salt and water is not clear. Significant quantities of salt (predominantly chloride) and water may be associated with the solid phase of connective tissue $(35,36)$. Large stores of sodium are located in the crystal structure of bone; salt and water are contained in the gastrointestinal tract. The salt and water may derive, in part at least, from any one of these sources. In addition, an unknown fraction may be furnished by cells.

It is unlikely that venous obstruction so alters tissues in the congested area as to induce a local outpouring of salt and water. Most observers have concluded that muscle anoxia and injury in- 
duce a loss of intracellular potassium and a reciprocal gain of sodium $(37,38)$. The absence of an increase in plasma potassium or of a potassium diuresis suggests that no such cellular change occurred. Furthermore, the amount of salt available in the congested extremities (muscle cells are singularly free of sodium chloride [35]) appears inadequate to augment the extracellular fluid electrolyte by as much as 16 per cent. It is suggested, therefore, that the body tissue above the tourniquets may have supplied the bulk of endogenous salt and water. The amount of sodium chloride demonstrated to be contained outside of the inulin space is entirely adequate to supply $180 \mathrm{mEq}$. of sodium and $130 \mathrm{mEq}$. of chloride. Recent studies indicate that this degree of depletion would exhaust about one-fourth of the sodium and onethird of the chloride located outside of the inulin space $(14,15,20,39)$.

The increases in plasma protein concentration and hematocrit observed in the early stage of the tourniquet period are in accord with previous observations that tourniquets applied on the extremities at subdiastolic pressure produce a rapid reduction in plasma volume $(1,3)$. Whether any decrease in circulating volume, regardless of etiology, will initiate a movement of salt and water into the fluid phase of the extracellular compartment remains to be determined. Previous observations have suggested that DCA, cortisone, $\mathrm{ACTH}$, and whole adrenal cortical extract produce similar shifts $(17-19,21,40)$. The possibility, therefore, exists that this acute redistribution is similarly mediated through adrenal activity.

The tendency for the blood pressure to rise toward normal and for the serum protein concentration to fall in several subjects during the latter phase of the tourniquet period implies that some reconstitution of plasma volume was being accomplished. This reconstitution was abetted by a decreasing rate of plasma loss as local tissue pressure increased in the congested extremities (41). In addition, the endogenous expansion of the extracellular fluid volume may have enhanced the compensatory transfer of interstitial fluid into the depleted plasma in those areas of the capillary bed not exposed to increased pressure. Other investigators have demonstrated that the volume of the extracellular compartment in part determines the resistance of experimental animals to acute reductions in blood volume. Prior dehydration exaggerates the lethal effect of bleeding in dogs whereas prior saline infusions protect the animals $(6,42,43)$.

Reductions of GFR have been noted following interference with local venous return $(44,45)$. These changes have been attributed to the fall in blood pressure and to the generalized vasoconstriction in which the renal parenchyma is involved $(4,5,43)$. Because only two prolonged periods were obtained after tourniquet application, it is possible that in several subjects acute falls in GFR were obscured. The reduction in sodium excretion correlated only partly with the GFR as exemplified in those subjects where late in the tourniquet period sodium excretion continued to fall despite unchanged or increasing filtration rates (Table I, Figure 2). This phase of enhanced tubular reabsorption of salt coincided with the period of maximum redistribution of salt. Thus, these mechanisms, redistribution and retention, may be interdependent and complementary in retaining or augmenting extracellular fluid salt.

\section{CONCLUSIONS AND SUMMARY}

1. The volume of distribution of inulin, plasma electrolyte concentrations, plasma protein concentration, glomerular filtration rate, rate of electrolyte excretion, and blood pressure were measured serially before and during a two to three hour period in which tourniquets were applied at subdiastolic pressures to the thighs of eight human subjects. Comparable measurements were made at similar time intervals in two control subjects on whom tourniquets were not applied.

2. In each of the eight experimental subjects, two to three hours of venous congestion induced an expansion of the inulin space. The increase averaged 16 per cent with a range from 9 to 21 per cent. No consistent changes in plasma electrolyte concentrations were detected.

3. In five of the eight subjects, a reduction in glomerular filtration rate occurred. This reduction was most marked in the early phase of venous congestion. In five of seven subjects, a reduction in the rate of sodium excretion occurred. This reduction correlated only in part with the fall in glomerular filtration rate.

4. Transient falls in blood pressure were apparent in three of the eight subjects. Six sub- 
jects showed a slight to moderate increase in plasma protein concentration which reached maximal values after one to one and a half hours of venous congestion. Subsequently, in four subjects, these concentrations tended to return toward normal.

5. Two control subjects showed no change in GFR, inulin space, blood pressure, plasma electrolyte concentrations, or electrolyte excretion.

\section{REFERENCES}

1. Landis, E. M., Jonas, L., Angevine, M., and Erb, W., The passage of fluid and protein through the human capillary wall during venous congestion. J. Clin. Invest., 1932, 11, 717.

2. Ebert, R. V., and Stead, E. A., Jr., The effect of the application of tourniquets on the hemodynamics of the circulation. J. Clin. Invest., 1940, 19, 561.

3. Brown, E., Hopper, J., Jr., Sampson, J. J., and Murdrick, C., Venous congestion of the extremities in relation to blood volume determinations and to mixing curves of carbon monoxide and T-1824 in normal human subjects. J. Clin. Invest., 1951, 30, 1441.

4. Wiggers, C. J., Physiology of shock, New York, The Commonwealth Fund, 1950.

5. Richards, D. W., Jr., The circulation in traumatic shock in man. The Harvey Lectures, 1943-44, Series 39, 217.

6. Warren, J. V., Merrill, A. J., and Stead, E. A., Jr., The rôle of the extracellular fluid in the maintenance of a normal plasma volume. J. Clin. Invest., 1943, 22, 635.

7. Adolph, E. F., Gerbasi, M. J., and Lepore, M. J., The rate of entrance of fluid into the blood in hemorrhage. Am. J. Physiol., 1933, 104, 502.

8. Danowski, T. S., Elkinton, J. R., and Winkler, A. W., Movements of body water in response to acute blood loss. Am. J. Physiol., 1946, 147, 306.

9. Lands, A. M., and Johnson, W. H., Distribution of body water following hemorrhage. Proc. Soc. Exper. Biol. \& Med., 1942, 49, 123.

10. Stewart, J. D., and Rourke, G. M., Intracellular fluid loss in hemorrhage. J. Clin. Invest., 1936, 15, 697.

11. Katcher, A. L., Levitt, M. F., Sweet, A. Y., and Hodes, H. L., Studies on body water distribution in young infants; changes during recovery from diarrhea. Soc. for Ped. Research, Old Point Comfort, Va., May 1952 (abstract). Am. J. Dis. Child, in press.

12. Ashworth, C. T., and Kregel, L. A., Changes in the body water partition and extracellular electrolytes in shock. Arch. Surg., 1942, 44, 829.

13. Gaudino, M., Schwartz, I. L., and Levitt, M. F., Inulin volume of distribution as a measure of extracellular fluid in dog and man. Proc. Soc. Exper. Biol. \& Med., 1948, 68, 507.
14. Gaudino, M., and Levitt, M. F., Inulin space as a measure of extracellular volume. Am. J. Physiol., 1949, 157, 387.

15. Levitt, M. F., and Gaudino, M., Measurement of body water compartments. Am. J. Med., 1950, 9, 208.

16. Schwartz, I. L., Schacter, D., and Freinkel, N., The measurement of extracellular fluid in man by means of a constant infusion technique. J. Clin. Invest., 1949, 28, 1117.

17. Swingle, W. W., Parkins, W. M., Taylor, A. R., and Hays, H. W., Relation of serum sodium and chloride levels to alterations of body water in the intact and adrenalectomized dog, and the influence of adrenal cortical hormone upon fluid distribution. Am. J. Physiol., 1936, 116, 438.

18. Gaudino, M., and Levitt, M. F., Influence of the adrenal cortex on body water distribution and renal function. J. Clin. Invest., 1949, 28, 1487.

19. Levitt, M. F., and Bader, M. E., The influence of cortisone and ACTH on fluid and electrolyte distribution in man. Am. J. Med., 1951, 11, 715.

20. Crawford, B., and Gaudino, M., Changes in extracellular fluid volume, renal function, and electrolyte excretion induced by I-V saline infusions and by short periods of anaesthesia. Anaesthesiology, 1952, 13, 374.

21. Bloodworth, J. M. B., Jr., The acute effect of adrenal cortical extract, adrenocorticotropic hormone, and desoxycorticosterone acetate on the thiocyanate, bromide, and mannitol spaces; plasma volume and total body water in normal dogs. Endocrinology, 1952, 50, 174.

22. Calcagno, P. L., Husson, G. S., and Rubin, M. I., Measurement of "extracellular fluid space" in infants by equilibration technique using inulin and sodium ferrocyanide. Proc. Soc. Exper. Biol. \& Med., 1951, 77, 309.

23. Deane, N., Schreiner, G. E., and Robertson, J. S., The velocity of distribution of sucrose between plasma and interstitial fluid with reference to the use of sucrose for the measurement of extracellular fluid in man. J. Clin. Invest., 1951, 30, 1463.

24. Levitt, M. F., Turner, L. B., and Sweet, A. Y., Unpublished observations.

25. Schreiner, G. E., Determination of inulin by means of resorcinol. Proc. Soc. Exper. Biol. \& Med., 1950, 74, 117.

26. Smith, H. W., Finkelstein, N., Aliminosa, L., Crawford, B., and Graber, M., The renal clearances of substituted hippuric acid derivatives and other aromatic acids in dog and man. J. Clin. Invest., 1945, 24, 388.

27. Van Slyke, D. D., and Hiller, A., Application of Sendroy's iodometric chloride titration to protein containing fluids. J. Biol. Chem., 1947, 167, 107.

28. Kingsley, G. R., The determination of the serum total protein, albumin, and globulin by the biuret reaction. J. Biol. Chem., 1939, 131, 197. 
29. Berger, E. Y., Dunning, M. F., Steele, J. M., Jackenthal, R., and Brodie, B. B., Estimation of intracellular water in man. Am. J. Physiol., 1950, 162, 318.

30. Wallace. W. M., Some aspects of the chemical composition, physiology and pathology of intracellular fluid. Pediatrics, 1952, 9, 141.

31. Cotlove, E., Inulin and chloride space in muscle. Federation Proc., 1952, 11, 28.

32. Kruhoffer, P., Inulin as indicator for extracellular space. Acta physiol. scandinav., 1946, 11, 16.

33. Schwartz, I. L., Breed, E. S., and Maxwell, M. H., Comparison of the volume of distribution, renal and extrarenal clearances of inulin and mannitol in man. J. Clin. Invest., 1950, 29, 517.

34. Walser, M., Seldin, D. W., and Grollman, A., Measurement of extracellular fluid with radiosulfate. J. Clin. Invest., 1952, 31, 669.

35. Manery, J. F., and Hastings, A. B., The distribution of electrolytes in mammalian tissue. J. Biol. Chem., 1939, 127, 657.

36. Ludwig, A. W., The relation between connective tissue mucoprotein and electrolyte and water distribution. Bull. New York Acad. Med., in press.

37. Fox, C. L., Jr., and Baer, H., Redistribution of potassium, sodium and water in burns and trauma, and its relation to the phenomena of shock. Am. J. Physiol., 1947, 151, 155.

38. Brues, A. M., Cohn, W. E., Kety, S. S., Nathanson, I. T., Nutt, A. L., Tibbetts, D. M., Zamecnik, P.
C., and Aub, J. C., The toxic factors in experimental traumatic shock. II. Studies on electrolyte and water balance in shock. J. Clin. Invest., 1945, 24, 835.

39. Dunning, M. F., Steele, J. M., and Berger, E. Y., Measurement of total body chloride. Proc. Soc. Exper. Biol. \& Med., 1951, 77, 854.

40. Lichtwitz, A., Hioco, D., Parlier, R., Delaville, M., and Darroquy, J., Le compartiment intra-cellullaire dans l'insuffisance surrénale; carences hydrosodiques interstitielles et vasculaire de la maladie d'Addison. Semaine hôp. Paris, 1951, 27, 2911.

41. Landis, E. M., and Gibbon, J. H., Jr., The effects of temperature and tissue pressure on the movement of fluid through the human capillary wall. J. Clin. Invest., 1933, 12, 105.

42. Gilman, A., Experimental sodium loss analagous to adrenal insufficiency: the resulting water shift and sensitivity to hemorrhage. Am. J. Physiol., 1934, 108, 662.

43. Ingraham, R. C., and Wiggers, H. C., Alkalinizing agents and fluid priming in hemorrhagic shock. Am. J. Physiol., 1945, 144, 505.

44. Smith, H. W., Lectures on the Kidney, University Extension Division, University of Kansas, Lawrence, Kansas, 1939.

45. Farber, S. J., Alexander, J. D., and Eichna, L. W., Renal hemodynamics and salt and water excretion during induced congestion of the inferior vena cava of man. J. Clin. Invest., 1951, 30, 638. 